\title{
CHARGE증후군 1예
}

원광대학교 의과대학 이비인후과학교실, ${ }^{1}$ 방사선학과학교실 ${ }^{2}$

이재훈 ${ }^{1} \cdot$ 오차근 $^{1} \cdot$ 최진옥 $^{2}$

\section{A Case of CHARGE Syndrome}

Jae Hoon Lee, MD ${ }^{1}$, Cha Kun Oh, $\mathrm{MD}^{1}$ and Jin Ok Choi, $\mathrm{MD}^{2}$

${ }^{I}$ Department of Otolaryngology, and ${ }^{2}$ Radiology, College of Medicine, Wonkwang University, Iksan, Korea

\section{-ABSTRACT -}

Bilateral congenital choanal atresia, one of the most common nasal anomalies, is in need of emergency treatment in the otolaryngologic field. CHARGE syndrome is a very rare disease with six congenital malformations which are characterized by coloboma of the eye, hearing deficit, choanal atresia, retardation of growth, genital defect and endocardial cushion defect. We report a case of CHARGE syndrome that is composed with bilateral choanal atresia, hearing deficit, coloboma, patent ductus arteriosus and other anomaly such as hiatal hernia with reviewing reported references. (J Clinical Otolaryngol 2003;14:137-140)

KEY WORDS : Choanal atresia $\cdot$ CHARGE syndrome.

\section{서 론}

선천성후비공폐쇄증은 비교적 드문 질환이지만 국내 에서 간헐적으로 보고 되어왔다. ${ }^{1-4)}$ 그러나 CHARGE 증후군이 동반된 경우는 국내의 보고에서는 매우 드물 다. ${ }^{3)} \mathrm{CHARGE}$ 증후군은 이비인후과 문제로 후비공폐쇄 증으로 인한 호흡곤란 및 청력 손실을 동반할 수 있으 며, 안과적 결손증(coloboma), 심장기형, 성장 장애, 중 추신경계의 지연발달 및 생식기 기형 등이 동반될 수 있다. 저자들은 최근 $\mathrm{CHARGE}$ 증후군 1예를 경험하였 기에 문헌 고찰과 함께 보고하는 바이다.

논문접수일 : 2002년 12월 31일

심사완료일 : 2003년 4월 6일

교신저자 : 이재훈, 570- 711 전북 익산시 신용동 344- 2

원광대학교 의과대학 이비인후과학교실

전화 : (063) 850- 1310. 전송 : (063) 841- 6556

E- mail : coolnose@wonnms.wonkwang.ac.kr

\section{증 례}

생후 1일된 여자 환아로 개인 산부인과에서 41주, $3,550 \mathrm{gm}$ 으로 정상 분만하에 태어났으며, 아프가 점수 (A pgar score) 는 1분/5분에 각각 8점과 9점이었다. 출 생 당시부터 발생한 호흡곤란, 청색증, 빈호흡, 흉곽 함 몰이 보여 본원 신생아 중환자실로 전원 되었다. 가족력 상 특이 소견 없었으며 분당 86회의 빈호흡을 보였다. 수유시 발생하는 청색증이 있어 비위장관 튜브(nasogastric tube)를 비강을 통해 여러 차례 삽입하려고 하였 으나 실패한 후 비인강내 질환을 의심하여 이비인후과 로 의뢰되었다. 비내시경을 이용한 검사에서 양측 후비 공폐쇄를 확인하였고, 즉시 McGovern nipple을 착용하 게 하였다. 그 후 실시한 부비동 전산화 단층 촬영에서 양측 후비공이 막성으로 폐쇄된 소견이 보였으며 서골 의 나비와 후비공의 직경은 정상적인 소견을 보였다 (Fig. 1).

환아는 전신마취 하에서 $4 \mathrm{~mm}$ 비내시경을 이용하여 


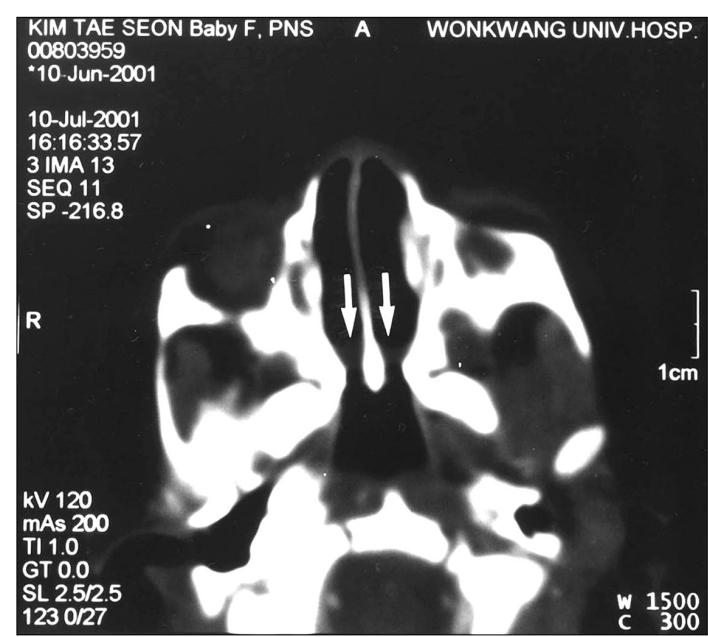

Fig. 1. Bilateral membranous choanal atresia in an infant. Axial CT shows soft-tissue membranes (arrows) extending from the lateral aspects of the vomer to the medial and posterior maxilla. The width of the vomer and the diameter of the posterior choanae are normal in this patient.

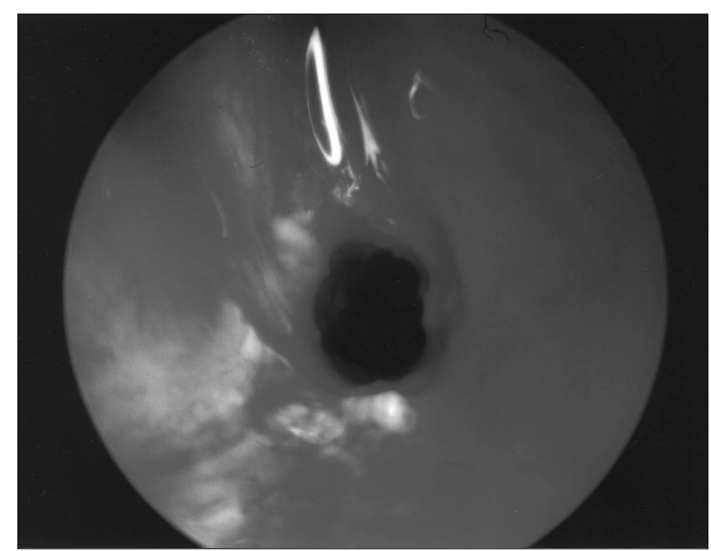

Fig. 2. Intraoperative picture of a newly formed rightsided choanae.

막성 폐쇄판을 확인 후 $\mathrm{Nd}: \mathrm{YAG}$ 레이저를 이용하여 막성 폐쇄판을 제거한 후(Fig. 2), 스텐트로 $4 \mathrm{~mm}$ 실리 콘 관을 비강내 유치하였고 비중격주위 봉합술(circumseptal suture) 을 이용하여 비강내 고정하였다.

수술 후 동반된 기형유무를 확인하기 위한 검사에서 육안적으로 외이의 기형은 없었으며 양측 고막은 정상 소견을 보였으나 뇌간유발청력 검사 상 양측 귀에서 전 혀 반응이 나타나지 않았다. 심초음파 검사에서는 심부
전증을 동반한 동맥관개존증(patent ductus arteriosus) 으로 진단 받았다. 안과적 검사에서 환아는 우안에 비해 좌안의 안구가 작은 소안구증(microphthalmia) 을 보였고, 각막 크기는 우안이 $10 \mathrm{~mm}$ 에 비해 좌안이 $6 \mathrm{~mm}$ 로 작았으며, 좌안의 홍채, 안저, 시신경유두 및 망막의 결손증(coloboma)을 보였다. 시각 뇌유발 전위 검사에 서는 우안에 비해 좌안에서 잠복기가 증가되었다. 뇌 이 상 유무 확인을 위한 뇌 자기공명영상을 실시하였으나 이상 소견은 보이지 않았다. 상부 위장관 촬영 및 흉부 전산화 단층 촬영에서는 흉곽내에 위가 존재하여 열공 탈장(hiatal hernia) 으로 밝혀졌다.

비강내 유치된 스텐트는 수술 후 6 주째 제거하였다. 수술 후 4개월째 우측 비강이 폐쇄된 소견을 보여 $\mathrm{Nd}$ : YAG 레이저를 이용하여 재차 우측 후비공폐쇄증 개방 술을 시행하고 스텐트를 8주 동안 유치시켰다. 재수술 후 6 개월 추적 관찰하였으나, 폐쇄된 소견은 보이지 않 았다. 열공탈장으로 타 병원에서 두 차례 수술을 받았고 추적 관찰중이다.

\section{고 찰}

선천성후비공폐쇄증은 신생아 5,000 명 내지 10,000 명당 한명의 발생률을 가지고 있고, 일반적으로 선천적 기형이 동반되지 않고 단독으로 발생되는 경우가 많지 만 약 10 15\% 에서 기형과 동반한다고 보고되어 있다. ${ }^{5)}$

CHA RGE 증후군은 Coloboma, Hearing deficit, A tresia choanae, Retardation of grow th, Genital defect, Endocardial cushion defect의 6 개의 선천성 질환을 가진 경우로 첫 앞 문자를 따서 명명하였으며,6) 이 중 최소 4 가지 질환을 가진 경우 진단할 수 있다. 그 외에 도 다지증( poly dactyly), 바- 아- 구개 기형(nasal- auricular and palatal deformities), Crouzon증후군, 두개 골 조기봉합(craniosy nostosis), 소두증(microencephaly), 뇌막류(meningocele), 수막쇠류(meningoencephalocele), 안면 비대칭, 눈과 안면의 발육부전, 구개 열, 양안격리증(hy pertelorism) 등이 동반될 수 있다. ${ }^{7)}$ CHARGE 증후군에서 후비공폐쇄증의 동반 비율은 연구 자에 따라 10 15\%, ${ }^{6)} 56 \%^{8}$ 라고 각각 보고 되었다. 또 한, Edward 증후군, ${ }^{2)}$ 점상연골형성장애(chondrody s- 
plasia punctata) ${ }^{4)}$ 에서도 후비공폐쇄증이 동반될 수 있 다고 보고되었다.

선천성후비공폐쇄증은 여자 대 남자의 비율은 보통 $2: 1$ 로 여자가 많고, 약 $70 \%$ 가 일측에서 발생한다. 양 측에서 선천성후비공폐쇄증이 발생된 경우 일측에서 발 생한 경우에 비해 다른 기형들이 같이 동반될 가능성이 많다. 폐쇄판의 구성은 골성이 $90 \%$, 막성이 $10 \%$ 를 차 지하는 것으로 알려져 왔으나, 다른 분류에 의하면 골성 이 $30 \%$, 골- 막 혼합성이 $70 \%$ 이고 순수한 막성은 찾 아볼 수 없다고 하였다. ${ }^{9}$ 이러한 후비공의 폐쇄가 발생 학적으로 일어날 수 있는 가설로 세가지가 알려져 있는 데, 첫째로는 협인두막(buccopharyngeal membra-ne) 이 지속적으로 존재하는 경우, 둘째로는 구개골의 수직 돌기와 수평돌기가 내측으로 과성장한 경우, 셋째로는 비협막(nasobuccal membrane) 이 없어지지 않고 남아 있는 경우이다. ${ }^{10)}$

$\mathrm{CHARGE}$ 증후군 환자의 대부분은 유전자 인자가 명 확하지 않으나 일부에서는 유전적 이상이 밝혀졌다. 유 전적 이상은 상염색체 우성과 열성 모두 나타난다고 보 고 있으며, 핵형 분석에서는 일반적으로 정상 소견을 보 인다고 보고되어 있다. ${ }^{3)}$ 다른 두경- 안면부 이상(craniofacial abnormality)이 동반되지 않았다면 자손들에게 유전될 확률은 거의 없는 것으로 보고되어 있다.6) 본 증례에서는 환아의 가족력상 특이 사항은 발견되지 않 았다.

CHARGE 증후군의 6가지 선천성 질환 중 안과적 결 손과 후비공폐쇄증이 가장 흔하다고 알려져 있다.8) 안 과적 질환으로는 홍채결손, 안저결손, 안검결손 등이 나 타난다. 심장 질환으로 Fallot 4 증후와 심실결손이 가 장 흔하게 나타나며, 중추신경계 지연으로 발육장애와 지능장애, 생식기 부전증 및 호르몬 이상증이 나타난다. 외이의 기형과 청력 손실이 발생할 수 있으며 청력 손 실은 이소골의 기형과 등골건의 이상으로 인해 전도성 난청과 와우의 부전발달이나 신경의 이상으로 유발될 수 있으며 대부분 혼합성 난청이 발생된다. ${ }^{11)}$

후비공폐쇄증에 대한 수술접근법은 경구개법, 경비중 격법, 경상악동 수술접근법이 이용되어 왔으며, 근래에 는 주로 경비강법과 경구개법이 널리 이용되고 있다. 최 근 내시경을 이용한 경비강법 접근법으로 수술시야 확
보와 함께 다양한 기구를 이용하여 성공률을 높일 수 있다고 보고되고 있다. ${ }^{12-15)}$ 경비강법을 통해 폐쇄판을 제거하는 방법으로는 요도소식자 (urethral sound), microrongeur, 골겸자, 치과용 미세드릴, 레이저 등이 사 용될 수 있고, 레이저로는 $\mathrm{CO} 2, \mathrm{Nd}: \mathrm{YAG}, \mathrm{KTP}$, holmium : YAG 레이저를 사용할 수 있다. Healy 등히 은 CO2 레이저를 얇은 골성 폐쇄판에만 사용하였고 두 께가 $1 \mathrm{~mm}$ 가 넘는 두꺼운 폐쇄판에는 드릴 및 microrongeur를 사용하였다.

수술 후 재협착을 방지하기 위하여 스텐트를 유치하 는데 고무, 실리콘, 폴리에틸렌 등 다양한 재질을 사용 할 수 있으며 경성보다는 연성의 재질이 재협작 방지에 보다 도움을 줄 수 있다. 스텐트 유치기간은 3 12주로 다양하게 보고되어 있다. ${ }^{1-3) 15)}$ Prasad 등 ${ }^{17)}$ 은 국소용 mitomycin을 수술 후 개방된 후비공에 도포함으로써 재협착 방지와 더불어 스텐트 사용의 필요성을 줄일 수 있다고 보고하였다. 본 증례에서는 후비공이 순수 막성 폐쇄판으로 생각되어 $4 \mathrm{~mm}$ 내시경과 $\mathrm{Nd}: \mathrm{YAG}$ 레이저 를 이용하여 양측의 후비공 개방술을 실시하였으며, 재 협착 방지를 위해 스텐트를 6 주 동안 유치하였다. 그러 나 우측에서 수술 4 개월 후 협착이 발생하여 재수술을 시행하고 스텐트를 8주 동안 유치하였다. 재수술 후 6 개월까지 협착 소견은 보이지 않았다. 그 후로 추적관찰 중이다.

CHARGE 증후군의 예후로는 1년 생존율이 약 $70 \%$ 이고, 1 세 이전에 사망하는 경우는 분비물의 흡입에 의 한 것으로 알려져 있다. ${ }^{8)}$

본 증례는 $\mathrm{CHARGE}$ 증후군의 6가지 기형 중 안과적 결손, 동맥관개존증, 후비공폐쇄증, 청력소실의 4가지와 함께 열공탈장이 동반된 환아로 CHARGE 증후군의 진 단 기준에 합당하였다. 생식기 장애는 주로 남아에서 있 는데 본 증례는 여아이기 때문에 나타나지 않은 것으로 생각되었고, 발육 및 지능은 보다 더 추적 관찰이 필요 할 것으로 생각된다.

최근 저자들은 $\mathrm{CHARGE}$ 증후군 1예을 경험하여 문헌 고찰과 함께 보고하는 바이다.

중심 단어 : 후비공폐쇄증 CHARGE 증후군. 


\section{REFERENCES}

1) Jee BH, Kim YJ, Lee BJ. Four cases of choanal atresia managed by endoscopic endonasal repair. Korean J Otolaryngol 1999;42:1046-50.

2) Kim CH, Lee JG, Choi YS, Yoo YS, Yoon JH. Congenital choanal atresia: Analysis of 7 cases. Korean J Otolaryngol 2000;43:296-9.

3) Jung YJ, Kim YW, Kim HK, Yoon SW. A case of CHARGE Syndrome. Korean J Otolaryngol 2000;43:549-51

4) Park YK, Park JH, Ryu JS, Kim KS. A case of chondrodysplasia punctata combined with unilateral choanal atresia. Korean J Otolaryngol 2002;45:178-81.

5) Yeo SG, Park GY, Kim KJ, Kim JH. A case of congenital choanal atresia. J Clinical Otolaryngol 1998;9:336-41.

6) Pagon RA, Graham JM, Zonana J, Young SL. Congenital heart disease and choanal atresia with multiple anomalies: CHARGE association. J Pediatr 1981;99:223-7.

7) Brown K, Brown OE. Congenital malformations of the nose. In: Cummings CW, Fredrckson JM, Harker LA, Krause CJ, Schuller DE, editors. Otolaryngology-Head and Neck Surgery. 3rd ed. St. Lousi; Mosby Year Book: 1993. p.92-103.

8) Blake KD, Russell-Eggitt IM, Morgan DW, Ratcliff JM, Wyse RKH. Who's in CHARGE? Multidisciplinary management of patient's with CHARGE association. Arch Dis
Child 1990;65:217-23

9) Brown OE, Pownell P, Manning SC. Choanal atresia: A new anatomic classification and clinical management applications. Laryngoscope 1996;106:97-101.

10) Osguthorpe JD, Singleton GT, Adkins WY. The surgical approach to bilateral choanal atresia. Arch Otolaryngol 1982;108:366-9.

11) Davenport SL, Hefner MA, Mitchell JA. The spectrum of clinical feature in CHARGE syndrome. Clin Genet 1986; 29:298.

12) Morgan DW, Bailey CM. Current management of choanal atresia. Int J Pediatr Otolaryngol 1990;19:1-13.

13) Josephson GD, Vickery CL, Giles WC, Gross CW. Transnasal endoscopic repair of congenital choanal atresia. Arch Otolaryngol Head Neck Surg 1998;124:537-40.

14) Kamel R. Transnasal endoscopic approach in congenital choanal atresia. Laryngoscope 1994;104:642-6.

15) Lazar RH, Younis RT. Transnasal repair of choanal atresia using telescopes. Arch Otolaryngol Head Neck Surg 1995; 121:517-20

16) Healy GB, McGill T, Jako GJ, Storng MS, Vaughan CW. Management of choanal atresia with the carbon dioxide laser. Ann Otol Rhinol Laryngol 1978;87:658-62.

17) Prasad M, Ward R, April MM, Bent JP, Froehlich P. Topical mitomycin as an adjunct to choanal atresia repair. Arch Otolaryngol Head Neck Surg 2002;128:398-400. 